evels of positive end expiratory pressure. A preliminary study. Crit Care Med 1980;8:81-6.

4 Calvin JE, Driedger AA, Sibbald WJ. Positive end-expiratory pressure (PEEP) does not depress left ventricular function in patients with pulmonary edema. Am Rev Respir Dis 1981;124:121-8.

5 Prewitt RM, Oppenheimer L, Sutherland JB, Wood LDH. Effect of positive end-expiratory pressure on left ventricular mechanics in patients with hypoxemic respiratory failure. Anesthesiology 1981;55:409-15.

6 Ellman H, Dembin H. Lack of adverse hemodynamic effects of PEEP in patients with acute respiratory failure. Crit Care Med 1982;10:706-11

7 Grace MP, Greenbaum DM. Cardiac performance in response to PEEP in patients with cardiac dysfunction. Crit Care Med 1982;10:358-60.

8 Jardin F, Farcot J-C, Boisante L, Curien N, Margairaz A, Bourdarias JP. Influence of positive end-expiratory pressure on left ventricular performance. N kingl f Med 1981;304:387-92.

9 Schulman DS, Biondi JW, Matthay RA, Barash PG, Zaret B, Soufer R. Effect of positive end-expiratory pressure on right ventricular performance. Importance of baseline right ventricular function. Am J Med 1988;84:57-67.
10 Civetta JM. After quibbles and contrasts, concepts and caveats [Editorial]. Chest 1988;93:697-8.

11 Foote GA, Schabel SI, Hodges M. Pulmonary complications of the flowdirected balloon-tipped catheter. $N$ Engl I Med 1974;290:927-31.

12 Elliott CG, Zimmerman GA, Clemmer TP. Complications of pulmonary artery catheterisation in the care of critically-ill patients. A prospective study. Chest 1979;76:647-52.

13 Singer M, Bennett ED. Invasive hemodynamic monitoring in the United Kingdom. Enough or too little? Chest 1989;95:623-6.

14 Singer $M$, Clarke J, Bennett ED. Continuous hemodynamic monitoring b esophageal Doppler. Crit Cure Med (in press).

15 Bland JM, Altman DG. Statistical methods for assessing agreement between two methods of clinical measurement. L L ancet 1986;i:307-10.

16 Nelson LD, Houtchens BA, Westenkow DR. Oxvgen consumption and optimum PEEP in acute respiratory failure. Crit Care Med 1982;10:857-62.

(Accepted 23.March 1989)

\title{
Oral rehydration formula containing alanine and glucose for treatment of diarrhoea: a controlled trial
}

\author{
F C Patra, D A Sack, A Islam, A N Alam, R N Mazumder
}

\section{Abstract}

Objective-To determine whether adding L-alanine to the glucose based oral rehydration solution recommended by the World Health Organisation would improve its efficacy in treating acute diarrhoea.

Design-Randomised double blind controlled trial of oral rehydration solution containing $\mathrm{L}$-alanine and glucose.

Setting-Inpatient service of a hospital treating diarrhoea.

Patients-97 Male patients aged 6-59 years admitted to the hospital with acute and severe dehydration due to diarrhoea associated with Vibrio cholerae or enterotoxigenic Escherichia coli. Forty nine received the standard glucose based oral rehydration solution (control group) and 48 this solution with alanine added (study group).

Interventions - All of the patients received rapid intravenous acetate solution for the initial four hours after admission, which fully corrected the signs of dehydration. They were then admitted to the study and randomised. Immediately after the intravenous treatment oral rehydration treatment was started. All of the patients received oral tetracycline for $\mathbf{4 8}$ hours, starting 24 hours after start of the study. If signs of dehydration reappeared during oral treatment patients were given rapid intravenous acetate solution until they were fully corrected and then continued to take the assigned oral rehydration solution.

End point-Passage of the last watery stool.

Measurements and main results-The median stool output $/ \mathrm{kg}$ body weight during the initial 24 hours of oral rehydration treatment and until diarrhoea stopped was reduced in the study group compared with the control group from $309 \mathrm{ml}$ to $196 \mathrm{ml}$ and from $393 \mathrm{ml}$ to $236 \mathrm{ml}$ respectively. Intake of oral rehydration solution and intravenous acetate solution was reduced from $455 \mathrm{ml}$ to $308 \mathrm{ml}$ and from $616 \mathrm{ml}$ to $425 \mathrm{ml}$ respectively. Two patients in the study group compared with 18 patients in the control group required unscheduled rapid intravenous acetate solution to correct signs of dehydration during oral rehydration treatment.

Conclusion-Oral rehydration solution containing L-alanine was considerably better than standard oral rehydration solution at reducing the severity of symptoms and the need for fluid of male patients with diarrhoea associated with $V$ cholerae and enterotoxigenic $E$ coli.

\section{Introduction}

Treatment with glucose based oral rehydration solution is effective for preventing and treating diarrhoea. ${ }^{1-3}$ It does not, however, reduce the volume or frequency of stools or the duration of diarrhoea. ${ }^{+5}$ In 1984 , encouraged by results from several clinical trials, the diarrhoeal diseases control programme of the World Health Organisation began supporting research projects on developing improved oral rehydration solution formulation. ${ }^{6}$ Twenty eight such projects have been completed, are continuing, or are planned. Their aim is to compare the standard WHO oral rehydration solution with other formulations that have the same concentration of salts but may be more effective. There are two types of alternative formulation. One type contains glucose or a glucose polymer and an amino acid or a peptide, or both, in varying concentrations $^{6}$ : this approach was stimulated by studies in children ${ }^{7}$ and adults ${ }^{8}$ that used formulations containing glucose and glycine. In the other type of formulation glucose is replaced by a staple food (cereals, legumes, or roots) as a source of starch and protein: this approach was based on studies that showed that a rehydration solution containing 50 or $80 \mathrm{~g}$ of rice powder per litre in place of glucose can reduce stool volume substantially. ${ }^{910}$

Alanine has been proposed as a component of an improved oral rehydration solution formulation." Studies have shown that it enhances the absorption of sodium and water from the small intestine, the amount of absorption increasing with its concentration..$^{12}$ Alanine is a white, odourless, crystalline powder with a sweetish taste and is soluble in water; it is present in many foodstuffs and has been used as a dietary supplement. ${ }^{13}$ Alanine $50 \mathrm{~g}$ each day orally in divided doses reversed hypoglycaemia and ketosis and reduced catabolism of muscle in obese subjects starved for two weeks. ${ }^{14} \mathrm{~A}$ study of piglets with transmissible gastroenteritis showed that alanine with glucose caused a significantly greater absorption of sodium by the jejunal mucosa than either alanine or glucose alone. ${ }^{15}$

We report the results of a double blind randomised trial of an oral rehydration solution containing glucose and alanine.

\section{Patients and methods}

Male patients aged 6-59 years with a history of watery diarrhoea of 24 hours or less and clinical signs of severe dehydration were included in the study. Criteria for exclusion were: a history of treatment with anti- 
biotics within 24 hours of admission; complications other than those related directly to dehydration; an episode of diarrhoea during the two weeks before admission; clinical signs of severe malnutrition; large amounts of blood or mucus in stools; and refusal of informed consent. The study protocol was approved by the ethical review committee of this centre and the WHO. Before the study written consent was obtained from the patients or their legal guardians.

The sample size (49 patients in each treatment group) was calculated as being sufficient to detect a $25 \%$ decrease in stool output with a type I error of 0.05 and type II error of $0 \cdot 10$. Packets of the control and study oral rehydration solutions were provided by the diarrhoeal diseases control programme. They were identical in appearance and numbered sequentially according to a randomisation chart that was retained by the programme in Geneva. At the end of the study we were given the chart, which identified the two treatment groups. The full identity of the groups was provided only after the analysis was completed.

The study formulation contained glucose $90 \mathrm{mmol} / \mathrm{l}$ and alanine $90 \mathrm{mmol} / \mathrm{l}$, whereas the WHO formula, which was given to control patients, contained glucose $111 \mathrm{mmol} / \mathrm{l}$. The total osmolality of the study solution was $400 \mathrm{mmol} / \mathrm{kg}$, which was higher than that of the WHO solution $(331 \mathrm{mmol} / \mathrm{kg}$ ) but was considered to be within the limits of physiological tolerance. The salt content of the control and study formulations was identical-that is, sodium chloride $60 \mathrm{mmol} / \mathrm{l}$, potassium chloride $20 \mathrm{mmol} / \mathrm{l}$, and trisodium citrate dihydrate $10 \mathrm{mmol} / 1$.

Immediately after admission the weight and clinical signs of the patients were recorded and rapid intravenous rehydration with acetate solution was started. The amount of fluid given was calculated to replace the estimated deficit and the continuing stool losses; the intravenous solution contained sodium $134 \mathrm{mmol} / \mathrm{l}$, chloride $99 \mathrm{mmol} / \mathrm{l}$, potassium $13 \mathrm{mmol} / \mathrm{l}$, and the equivalent of bicarbonate (in the form of acetate) $48 \mathrm{mmol} / \mathrm{l}$. All patients received intravenous treatment for about four hours, which corrected the signs of dehydration completely. They were then admitted to the study and randomised. The patients were put on cholera cots for separate collection of stools and urine. Immediately after intravenous solution had been given oral rehydration treatment was started. Forty nine patients received the standard WHO oral rehydration solution (control group) and 48 patients the oral rehydration solution containing alanine (study group). The patients drank the solutions from cups as needed. The containers with the assigned solution and the cups were kept at the patients' bedsides. Intake of fluid and output of stools and urine were measured and vital signs summarised every eight hours until the patient was discharged from the study. The nurses were experienced in collection of metabolic samples. The patients fasted during the initial 24 hours of oral rehydration treatment, after which they were offered the standard hospital diet of rice, lentils, fish, and vegetables. Water was offered with the food. All patients received oral tetracycline for 48 hours $(500 \mathrm{mg}$ every six hours for adults and $50 \mathrm{mg} / \mathrm{kg} /$ day divided into four doses for children) starting 24 hours after the start of oral rehydration.

If signs of dehydration reappeared during oral rehydration with a rise in packed cell volume and specific gravity of plasma patients were again given rapid intravenous acetate solution until signs of dehydration were fully corrected and then given their assigned oral rehydration solution. Data from these patients were included in the analysis. Diarrhoea was considered to have stopped when the last liquid stool was passed. Patients were discharged from the study after passing the first formed stool.
On admission specimens of stools obtained with catheters or material from rectal swabs were cultured for Vibrio cholerae and enterotoxigenic Escherichia coli. Colonies of $E$ coli were tested for heat labile and heat stable enterotoxins by enzyme linked immunosorbent assay (ELISA). ${ }^{16}$ Venous blood was collected on admission (0 hours), when oral rehydration treatment was started (at about four hours), 24 hours after oral treatment was started, and at discharge. It was analysed for packed cell volume and specific gravity of plasma (Total Solid meter, American Optical Company). Serum sodium, potassium, and chloride and total carbon dioxide concentrations were measured with ion selective electrodes (Ion Selective ElectrodeE4 analyser, Beckman).

The two groups of patients were compared with regard to median (quartile) values and ranges of several variables on admission: age, weight, duration of diarrhoea before admission, number of stools, vomiting, proportion with history of vomiting, amount of intravenous fluid needed for initial rehydration, and pathogens isolated.

The distribution of important outcome variablesfor example, stool output $(\mathrm{ml} / \mathrm{kg})$, intake of oral rehydration solution $(\mathrm{ml} / \mathrm{kg})$, duration of diarrhoea (hours), total intake of salt solutions (that is, oral rehydration solutions and intravenous fluids $(\mathrm{ml} / \mathrm{kg})$ was evaluated. Most distributions were positively skewed, but $\log _{e}$ transformation rendered them negatively skewed. The outcome variables are therefore summarised as median (quartile) values and ranges. The Wilcoxon rank sum test for groups of independent samples was used to test outcome variables. The $\chi^{2}$ test was used for dichotomous variables - for example, the number of patients requiring unscheduled intravenous treatment.

\section{Results}

One patient in the study group was excluded from the analysis because a stool collected at the beginning of the study was accidentally lost. Three other patients in the study group were excluded because they had little purging after oral rehydration was started. Data on the two groups before intervention were comparable (table I). Enteropathogens, predominantly $V$

TABLE I-Presenting features of male patients with diarrhoea and severe dehydration. Figures are median (quartile) values except where stated otherwise

\begin{tabular}{|c|c|c|}
\hline & $\begin{array}{l}\text { Control group } \\
(n=49)\end{array}$ & $\begin{array}{c}\text { Study group } \\
(\mathrm{n}=48)\end{array}$ \\
\hline Age (years) & $23(14,35)$ & $28(19,37)$ \\
\hline Duration of diarrhoea before & $8-55$ & $6-50$ \\
\hline $\begin{array}{l}\text { admission }(h) \\
\text { Range }\end{array}$ & $\begin{array}{l}8(6,13) \\
4-24\end{array}$ & $\begin{array}{l}9(5,14) \\
4-24\end{array}$ \\
\hline No of stools before admission & $8(6,12)$ & $8(6,12)$ \\
\hline Range & $3-20$ & 4-30 \\
\hline No with history of vomiting & 44 & 47 \\
\hline Duration of vomiting $(\mathrm{h})$ & $5(4,8)$ & $5(4,10)$ \\
\hline Range & $0-24$ & $0-24$ \\
\hline No of vomits & $5(2,7)$ & $5(3,8)$ \\
\hline Range & $0-20$ & $0-15$ \\
\hline Weight on admission $(\mathrm{kg})$ & $39 \cdot 5(28 \cdot 5,43 \cdot 4)$ & $39 \cdot 5(35 \cdot 3,43 \cdot 9)$ \\
\hline Range & $12-50$ & $14-50$ \\
\hline \multicolumn{3}{|c|}{ Amount of intravenous fluid needed for } \\
\hline initial rehydration $(\mathrm{ml} / \mathrm{kg})$ & $133(116,172)$ & $126(115,142)$ \\
\hline Range & $95-273$ & $65-205$ \\
\hline \multicolumn{3}{|l|}{ No with pathogens isolated: } \\
\hline Classical $V$ cholerae & 16 & $15^{\star}$ \\
\hline El Tor V cholerae & 16 & 11 \\
\hline No with enterotoxigenic $E$ coli & 10 & $15^{\star}$ \\
\hline Heat stable and heat labile & 7 & 4 \\
\hline Heat stable & 2 & 7 \\
\hline Heat labile & 1 & 4 \\
\hline \multicolumn{3}{|l|}{ No with combined infection with } \\
\hline $\begin{array}{l}\text { Classical } V \text { cholerae and } \\
\text { enterotoxigenic } E \text { coli (heat labile) }\end{array}$ & 0 & 2 \\
\hline Total $(\%)$ with pathogens isolated & $42(86)$ & $39(81)$ \\
\hline
\end{tabular}

${ }^{\star}$ Includes two patients who had $V$ cholerue and enterotoxigenic $E$ coli isolated from cultures. 
TABLE II -Clinical course of illness, stool and urine outputs, intakes of oral rehydration solution and water, and duration of diarrhoea in male patients with diarrhoea during treatment for severe dehydration. Figures are median (quartile) values except where stated otherwise

\begin{tabular}{|c|c|c|c|c|}
\hline & $\begin{array}{l}\text { Control group } \\
(n=49)\end{array}$ & $\begin{array}{l}\text { Study group } \\
(\mathrm{n}=45)\end{array}$ & $\begin{array}{l}95 \% \text { Confidence } \\
\text { interval for } \\
\text { difference } \\
\text { between means }\end{array}$ & $\mathrm{p}$ Value \\
\hline No who vomited during oral treatment & 24 & 14 & & $0 \cdot 12 \dagger$ \\
\hline \multicolumn{5}{|l|}{ Stool output $(\mathrm{ml} / \mathrm{kg})$ : } \\
\hline $\begin{array}{l}\text { During first } 24 \mathrm{~h} \\
\text { Range }\end{array}$ & $\begin{array}{l}309(209,419) \\
7-744\end{array}$ & $\begin{array}{l}196(114,279) \\
8-452\end{array}$ & 64 to 183 & $0 \cdot 0001$ \\
\hline $\begin{array}{l}\text { Total } \\
\text { Range }\end{array}$ & $393(274,576)$ & $236(128,376)$ & 97 to 298 & $0 \cdot 0003$ \\
\hline \multicolumn{5}{|l|}{ Intake of oral rehydration solution $(\mathrm{ml} / \mathrm{kg})$ : } \\
\hline $\begin{array}{l}\text { During first } 24 \mathrm{~h}^{\circ} \\
\text { Range }\end{array}$ & $\begin{array}{l}391(288,514) \\
101-955\end{array}$ & $\begin{array}{c}300(221,412) \\
59-675\end{array}$ & 5 to 139 & 0.036 \\
\hline $\begin{array}{l}\text { Total } \\
\text { Range }\end{array}$ & $\begin{array}{l}574(457,720) \\
105-1719\end{array}$ & $\begin{array}{l}416(276,577) \\
60-1035\end{array}$ & 39 to 268 & $0 \cdot 004$ \\
\hline $\begin{array}{l}\text { Total intake of water }(\mathrm{ml} / \mathrm{kg}) \\
\text { Range }\end{array}$ & $\begin{array}{r}39(9,56) \\
0-164\end{array}$ & $\begin{array}{r}25(6,53) \\
0-136\end{array}$ & $-2 \cdot 0$ to $12 \cdot 4$ & $0 \cdot 36$ \\
\hline $\begin{array}{l}\text { Duration of diarrhoea }(\mathrm{h}) \\
\text { Range }\end{array}$ & $\begin{array}{c}52(36,60) \\
20-108\end{array}$ & $\begin{array}{l}44(36,60) \\
12-92\end{array}$ & -1 to 14 & $0 \cdot 10$ \\
\hline \multicolumn{5}{|l|}{ Urine output $(\mathrm{m} / \mathrm{kg})$ : } \\
\hline $\begin{array}{l}\text { During first } 24 \mathrm{~h} \\
\text { Range }\end{array}$ & $\begin{array}{c}99(43,134) \\
4-271\end{array}$ & $\begin{array}{c}87(60,128) \\
5-221\end{array}$ & $-8 \cdot 9$ to $14 \cdot 5$ & 0.66 \\
\hline $\begin{array}{l}\text { Total } \\
\text { Range }\end{array}$ & $\begin{array}{c}172(96,278) \\
19-614\end{array}$ & $\begin{array}{c}169(103,230) \\
38-519\end{array}$ & $-2 \cdot 2$ to $44 \cdot 4$ & $0 \cdot 40$ \\
\hline \multicolumn{5}{|l|}{$\begin{array}{l}\text { Intake of oral and intravenous rehydration } \\
\text { solutions }(\mathrm{ml} / \mathrm{kg}) \text { : }\end{array}$} \\
\hline $\begin{array}{l}\text { During first } 24 \mathrm{~h} \\
\text { Range }\end{array}$ & $\begin{array}{l}455(364,568) \\
101-955\end{array}$ & $\begin{array}{l}308(231,422) \\
59-675\end{array}$ & 49 to 190 & $0 \cdot 001$ \\
\hline $\begin{array}{l}\text { Total } \\
\text { Range }\end{array}$ & $\begin{array}{l}616(490,919) \\
105-1856\end{array}$ & $\begin{array}{c}425(276,592) \\
60-1241\end{array}$ & 103 to 371 & 0.0006 \\
\hline $\begin{array}{l}\text { No receiving unscheduled intravenous } \\
\text { rehydration solution during study period }\end{array}$ & 18 & 2 & & $<0.0004 \dagger$ \\
\hline
\end{tabular}

*Wilcoxon rank sum test for independent samples. t $x^{2}$ test.

TABLE III-Biochemical measurements taken in male patients with diarrhoea during treatment for severe dehydration

\begin{tabular}{|c|c|c|c|c|}
\hline & \multicolumn{2}{|c|}{ Control group } & \multicolumn{2}{|l|}{ Study group } \\
\hline & $\begin{array}{c}\text { Mean } \\
\text { (SD) value }\end{array}$ & No & $\begin{array}{c}\text { Mean } \\
(\mathrm{SD}) \text { value }\end{array}$ & No \\
\hline \multicolumn{5}{|c|}{ Specific gravity of plasma: } \\
\hline On admission $(0 \mathrm{~h})$ & $1.036(0.003)$ & 39 & $1.035(0.004)$ & \\
\hline At $4 h^{\star}$ & $1.025(0.002)$ & 47 & $1.024(0.002)$ & 45 \\
\hline At $28 \mathrm{~h}$ & $1.027(0.004)$ & 48 & $1.026(0.002)$ & 41 \\
\hline At discharge & $1.026(0.001)$ & 48 & $1.026(0.001)$ & 40 \\
\hline \multicolumn{5}{|l|}{ Packed cell volume: } \\
\hline On admission $(0 \mathrm{~h})$ & $0.57(0.07)$ & 49 & $0.56(0.07)$ & 45 \\
\hline At $4 h^{\star}$ & $0.39(0.05)$ & 49 & $0.40(0.05)$ & 45 \\
\hline At $28 \mathrm{~h}$ & $0.44(0.08)$ & 49 & $0.42(0.05)$ & 45 \\
\hline At discharge & $0.41(0.06)$ & 48 & $0.42(0.05)$ & 41 \\
\hline \multicolumn{5}{|l|}{ Serum sodium $(\mathrm{mmol} / \mathrm{l})$ : } \\
\hline On admission $(0 \mathrm{~h})$ & $133.9(2 \cdot 4)$ & 49 & $134 \cdot 3(2 \cdot 7)$ & 44 \\
\hline At $4 h^{\star}$ & $137 \cdot 3(2 \cdot 7)$ & 48 & $137 \cdot 8(2 \cdot 5)$ & 45 \\
\hline At $28 \mathrm{~h}$ & $135 \cdot 8(3 \cdot 7)$ & 49 & $137 \cdot 0(3 \cdot 3)$ & 44 \\
\hline At discharge & $137 \cdot 2(2 \cdot 3)$ & 48 & $137 \cdot 2(2 \cdot 1)$ & 41 \\
\hline \multicolumn{5}{|c|}{ Serum potassium $(\mathrm{mmol} / \mathrm{l})$ : } \\
\hline On admission $(0 \mathrm{~h})$ & $4 \cdot 8(1 \cdot 0)$ & 47 & $4 \cdot 7(0 \cdot 7)$ & 44 \\
\hline At $4 h^{\star}$ & $4 \cdot 8(0 \cdot 7)$ & 48 & $4 \cdot 6(0 \cdot 5)$ & 45 \\
\hline At $28 \mathrm{~h}$ & $4 \cdot 8(0 \cdot 8)$ & 49 & $4 \cdot 7(0 \cdot 5)$ & 44 \\
\hline At discharge & $4 \cdot 0(0 \cdot 4)$ & 48 & $4 \cdot 0(0 \cdot 4)$ & 41 \\
\hline \multicolumn{5}{|c|}{ Serum chloride $(\mathrm{mmol} / \mathrm{l})$ : } \\
\hline On admission $(0 \mathrm{~h})$ & $103 \cdot 7(4 \cdot 6)$ & 47 & $103 \cdot 6(4 \cdot 8)$ & 44 \\
\hline At $4 h^{\star}$ & $105 \cdot 3(4 \cdot 7)$ & 48 & $105 \cdot 8(3 \cdot 5)$ & 4 \\
\hline At $28 \mathrm{~h}$ & $104 \cdot 0(6 \cdot 6)$ & 49 & $106.0(3.9)$ & 43 \\
\hline At discharge & $103 \cdot 2(3 \cdot 0)$ & 48 & $102 \cdot 1(3 \cdot 4)$ & \\
\hline \multicolumn{5}{|l|}{$\begin{array}{l}\text { Plasma carbon dioxide } \\
(\mathrm{mmol} / \mathrm{l}) \text { : }\end{array}$} \\
\hline On admission $(0 \mathrm{~h})$ & $13 \cdot 9(3 \cdot 5)$ & 46 & $14 \cdot 6(3 \cdot 5)$ & 44 \\
\hline At $4 h^{\star}$ & $21 \cdot 9(3 \cdot 0)$ & 48 & $22 \cdot 7(3 \cdot 3)$ & 45 \\
\hline At $28 \mathrm{~h}$ & $22.9(3.8)$ & 49 & $23 \cdot 6(4 \cdot 2)$ & 44 \\
\hline At discharge & $25 \cdot 8(2 \cdot 5)$ & 48 & $26 \cdot 6(2 \cdot 7)$ & 41 \\
\hline
\end{tabular}

$\star$ Start of treatment with oral rehydration solution.

cholerae, were isolated from $84 \%$ of the patients Thirty two patients in the control group and 26 in the study group were positive for $V$ cholerae. Separate analysis of patients whose cultures grew $V$ cholerae gave results that were nearly identical with those obtained from all patients. Therefore results of combined analysis irrespective of the cause of the diarrhoea is given.

Table II shows that in the study group compared with the control group the median stool output $/ \mathrm{kg}$ body weight during the initial 24 hours of oral rehydration treatment and until diarrhoea stopped was reduced by $37 \%$ ( $309 \mathrm{ml}$ to $196 \mathrm{ml} ; \mathrm{p}=0.0001$ ) and $40 \%$ ( $393 \mathrm{ml}$ to $236 \mathrm{ml} ; \mathrm{p}=0.0003$ ) respectively; intake of oral rehydration solution $/ \mathrm{kg}$ during the initial 24 hours and until diarrhoea stopped was reduced by $23 \%$
$(391 \mathrm{ml}$ to $300 \mathrm{ml} ; \mathrm{p}=0.036)$ and $27 \%(574 \mathrm{ml}$ to $416 \mathrm{ml} ; \mathrm{p}=0.004)$ respectively; total intake of salt solutions $/ \mathrm{kg}$ - that is, oral rehydration solution and intravenous fluid-during the initial 24 hours of oral rehydration treatment and until diarrhoea stopped was reduced by $32 \%$ ( $455 \mathrm{ml}$ to $308 \mathrm{ml} ; \mathrm{p}=0.001$ ) and $31 \%$ $(616 \mathrm{ml}$ to $425 \mathrm{ml} ; \mathrm{p}=0.0006)$ respectively; and duration of diarrhoea was reduced by $15 \%$ ( 52 hours to 44 hours; $p=0 \cdot 10$ ). Similar results were noted when only patients with cultures that grew $V$ cholerae were included in the analysis: the mean (SD) total stool output in the control and study groups was 578 (272) and $337(126) \mathrm{ml} / \mathrm{kg}(\mathrm{p}=0.0001)$ respectively (a reduction of $42 \%$ ). Eighteen patients in the control group needed additional intravenous solution after starting oral rehydration treatment compared with only two patients in the study group $(\mathrm{p}<0.0004)$.

Values for specific gravity of plasma and packed cell volume on admission and during treatment were closely similar in the two groups (table III), which was to be expected, 20 patients showing signs of dehydration after starting oral rehydration treatment were rehydrated promptly with intravenous solution. Serum electrolyte and total carbon dioxide concentrations were also similar in the two groups. None of the patients in either group had hypernatraemia on admission, nor did any of the patients develop it during treatment.

\section{Discussion}

Our results show that an oral rehydration solution containing alanine and glucose enhanced absorption in adults and older children with severe diarrhoea associated with $V$ cholerae and enterotoxigenic $E$ coli. In addition it considerably reduced the need for additional intravenous fluids after initial rehydration. The results suggest that the test solution was absorbed more efficiently than the standard solution, even though it had a higher osmolality, which may have imposed an "osmotic penalty." This penalty may be overcome by reducing the glucose or L-alanine concentration or by replacing glucose with glucose polymers.

The estimated efficacy of the solution may be considered to be conservative, because three patients from the study group with little purging after oral rehydration was started were excluded from the analysis; also, after starting oral rehydration treatment 18 patients in the control group compared with two in the study group received additional intravenous solution which may have reduced their faecal output. An oral rehydration solution containing L-alanine may play a potentially important part in treating o dehydrated patients with cholera during epidemics where it is difficult to provide facilities for intravenous treatment. Results from earlier studies have indicated that, despite treatment with antibiotics from the start, about $16 \%$ of severely dehydrated patients with cholera after initial intravenous rehydration required unscheduled intravenous solution during treatment with glucose oral rehydration solution. ${ }^{57-19}$ In this study no antibiotic was administered until 24 hours after admission, and therefore a large proportion of patients in the control group (37\%) required unscheduled intravenous treatment. Only $4 \%$ of those who received oral rehydration solution containing alanine, however, needed unscheduled intravenous treatment. A significant difference was not observed in the duration of diarrhoea between the two groups; this was probably because all of the patients received tetracycline.

In other studies the addition of another amino acid, glycine, to glucose oral rehydration solution improved absorption of fluid and reduced stool volume during acute diarrhoea caused mostly by toxigenic bacteria $(V$ cholerae 01 , enterotoxigenic $E$ coli $) .{ }^{78}$ A study 
conducted in Indonesian adults with severe cholera confirmed these findings and showed a 19\% reduction in stool output with oral rehydration solution containing glucose and glycine compared with the standard oral rehydration solution. ${ }^{6}$ On the other hand, results from six studies in children under 3 years with acute diarrhoea, including diarrhoea associated with rotavirus, showed that the addition of glycine and, in some studies, glycyl-glycine to glucose oral rehydration solution had no consistent beneficial effect on the stool output, intake of oral rehydration solution, or duration of diarrhoea. ${ }^{62021}$

Our results support the concept that absorption of sodium and water can be increased significantly by adding an amino acid to the oral rehydration solution. Before a new formula for oral rehydration solution is proposed, however, several studies should be conducted to determine the efficacy of the new solution in treating diarrhoea of various origins in young children; the optimal osmolality of the solution and the optimal amino acid concentration; and whether other amino acids might be even more efficacious than alanine in promoting absorption of salts and water.

This research was supported by a grant from the Programme for Control of Diarrhoeal Diseases, World Health Organisation, Geneva. We thank Dr Dilip Mahalanabis for proposing this study and his help in statistical analysis and preparing the manuscript; Dr Roger Eeckels for his support and his critical review of the manuscript; the staff of the clinical research centre for their help; and $\mathrm{Mr}$ Meer Mohammed Ramzan Ali and Ms Loretta Saldanha for secretarial help.

1 Anonymous. Oral glucose/electrolyte therapy for acute diarrhoea [Editorial] Lancet 1975;i:79-80.
Anonymous. Oral therapy for acute diarrhoea [Editorial]. Lancet 1981 ;ii: $615-7$

The time has come [Editorial]. Lancet 1983;ii:259.

4 Sack DA, Chowdhury AMAK, Eusof A, et al. Oral hydration in rotavirus diarrhoea: a double blind comparison of sucrose with glucose electrolyte solution. Lancet 1978;ii:280-3.

5 Pierce NF, Sack RB, Mitra RC, et al. Replacement of water and electrolyte losses in cholera by an oral glucose electrolyte solution. Ann Intern Med 1969;70:1173-81

6 World Health Organisation. Sixth programme report 1986-1987: programme for control of diarrhoeal disease. Geneva: WHO, 1988:42-6. (WHO/CDD/88.28.)

Patra FC, Mahalanabis D, Jalan KN, Sen A, Baneriee P. In search of a super solution: controlled trial of glycine-glucose oral rehydration solution in infantile diarrhoea. Acta Paediatr Scand 1984;73:18-21.

8 Nalin DR, Cash RA, Rahman M, Yunus MD. Effect of glycine and glucose on odium and water absorption in patients with cholera. Gut 1970;11:768-72.

Parr FC, Mahalabis D, Jalan KN, Sen A, Ban . solution superior to glucose
Dis Child 1982:57:910-2.

10 Molla AM, Ahmed SM, Greenough WB. Rice-based oral rehydration solution decreases the stool volume in acute diarrhoea. Bull WHO 1985;63:751-6.

11 Mahalanabis D. Development of an improved formulation of oral rehydration salts $(O R S)$ with antidiarrhoeal and nutritional properties: a "super ORS." Geneva: WHO, 1985:7-8. (WHO. CDD/DDM/85.3.)

2 Hellier MD, Thirumalai $C$, Holdsworth CD. The effect of amino acids and dipeptides on sodium and water absorption in man. Gut 1973;14:41-5.

13 Reynolds JEF, ed. Martindale; the extra pharmacopoeia. 28th ed. London: Pharmaceutical Press, 1982:48.

14 Genuth SM. Effects of oral alanine administration in fasting obese subjects. Metabolism 1973;22:927-37.

15 Rhoads JM, Macleod RJ, Hamilton JR. Alanine enhances jejunal sodium absorption in the presence of glucose: studies in piglet viral diarrhea. Pediatr Res 1986;20:879-83.

16 World Health Organiation. Manual for laboratory investigations of acute enteric infections. Revised ed. Geneva: WHO, 1987:42-58. (WHO/CDD/83.3.)

17 Nalin DR, Cash RA, Islam R, Molla AM, Phillips RA. Oral maintenance therapy for cholera in adults. Lancet 1968 ;ii:370-2.

18 Sack RB, Cassels J, Mitra RC, et al. The use of oral replacement solutions in the treatment of cholera and other severe diarrhoeal disorders. Bull WHO the treatment of

19 Palmer DL, Koster FT, Islam AFMR, Rahman ASMM, Sack RB. Comparison of sucrose and glucose in the oral electrolyte therapy of cholera an other severe diarrheas. N Engl I Med 1977;297:1 107-9.

20 Santosham M, Burns BA, Reid R, et al. Glycine-based oral rehydration solution: reassessment of safety and efficacy. $\mathcal{F}$ Pediatr 1986;109:795-801.

21 Vesikari T, Isolauri E. Glycine supplemented oral rehydration solutions for diarrhoea. Arch Dis Child 1986;61:372-6.

(Accepted I March 1989)

\section{Paradoxical survival of elderly men with high blood pressure}

\section{Robert D Langer, Theodore G Ganiats, Elizabeth Barrett-Connor}

Department of Community and Family Medicine, University of California, San Diego, California 92093, United States Robert D Langer, $\mathrm{MD}$, assistant adjunct professor Theodore G Ganiats, MD, associate clinical professor Elizabeth Barrett-Connor, $\mathrm{MD}$, professor

Correspondence to: $\mathrm{Dr}$ Langer.

Br.Hed 7 1989:298:1356-8
A recent study in Finland found a paradoxical graded positive association between blood pressure and survival in people aged 85 and over. ${ }^{1}$ Other studies have shown a lack of association between hypertension and mortality in elderly people but not this unexpected advantage in terms of survival, possibly because they had too few very old subjects. ${ }^{2-4}$ We tested this relation in another cohort.

\section{Patients, methods, and results}

In 1972-4 all adults living in a predominantly white, upper middle class retirement community were invited to a cardiovascular screening programme in which blood pressure was measured with a mercury sphygmomanometer after the subject had been seated for five minutes; $4382(82 \%)$ participated. All 2270 participants aged $\geqslant 65$ at the start of the study were evaluated. Vital states after 10 years was known for 2268 subjects (99.9\%); death certificates were obtained for all people who had died. Deaths were coded with the International Classification of Disease, ninth revision; codes 400-438 were taken to represent cardiovascular disease.

After 10 years there had been 448 deaths in 1159 men and 254 deaths in 1109 women, giving an overall mortality of $31 \%$. Cardiovascular disease caused 320 $(71 \%)$ deaths in men and $149(59 \%)$ in women. Subjects were divided into three age groups and four categories each of diastolic and systolic blood pressure based on distribution. Relative survival by category of blood pressure was calculated with Kaplan-Meier techniques for all cause and cardiovascular mortality. Results were tested with the $\chi^{2}$ test for trend. Because of the difference in cardiovascular mortality between the sexes we analysed these effects separately for men and women.

The table shows the results. In men aged $\geqslant 75$ low diastolic blood pressure was associated with the greatest all cause $(p=0.04)$ and cardiovascular $(p=0.02)$ mortality and higher diastolic blood pressure predicted survival. By contrast, in younger men and in women of all age groups the usual positive association between blood pressure and death due to all causes or cardiovascular disease was found.

\section{Comment}

Our analysis confirms a paradoxical graded survival advantage in men aged $\geqslant 75$ with increasing diastolic blood pressure for both all cause and cardiovascular mortality. This relation was not seen in women or younger men. The relation between systolic blood pressure and survival was not conclusive.

The previous study of this relation from Finland looked at mainly women (82\%) and results were for both sexes combined. ${ }^{1}$ In the present study, which included similar numbers of men and women, we were unable to find a positive relation between blood pressure and survival in women. Our population was younger than the Finnish cohort: in the $\geqslant 75$ age group the mean age was $78 \cdot 1$ years $(78 \cdot 0$ for men and $78 \cdot 3$ for women), whereas the mean age in the Finnish cohort was 88.4 years. The strong inverse relation seen in the oldest men between diastolic blood pressure and cardiovascular death and the high proportion of deaths 